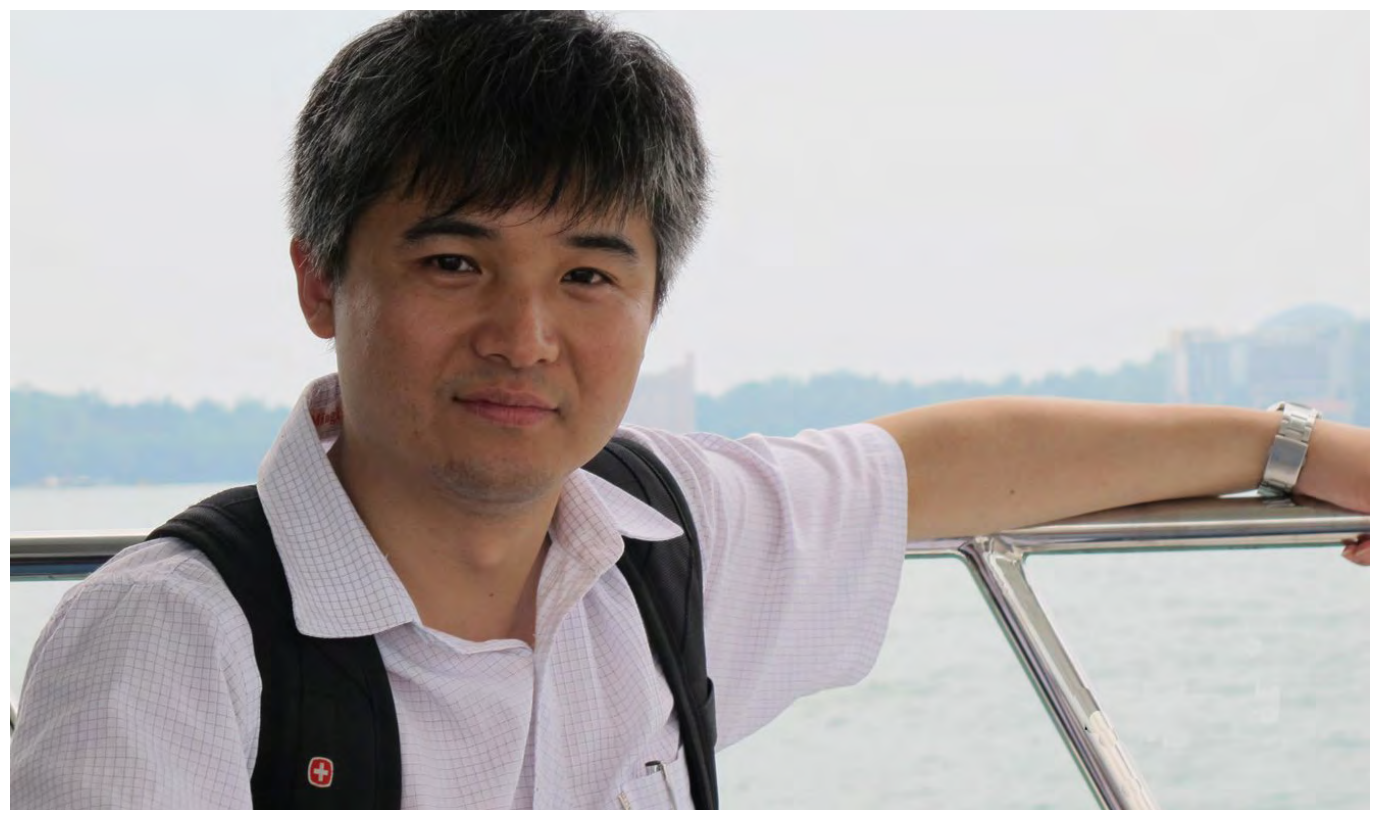

\title{
The Yirenping \\ Experience
}

Lu Jun. PC: Yirenping.

\author{
Looking Back and Pushing \\ Forward
}

LU Jun

The Beijing Yirenping Centre was one of the most remarkable grassroots nongovernmental organisations (NGOs) to emerge in China during the $\mathrm{Hu}$ and Wen era. Through an innovative mix of strategies, including legal litigation, public advocacy, and performative arts, the centre was able to promote significant policy changes in its field of operation-that is, anti-discrimination-before being shut down at the onset of the Xi Jinping era. We asked Lu Jun, the co-founder and one of the main forces behind the organisation, to reflect on the Yirenping experience and what it means for the future of Chinese civil society.

The Editors

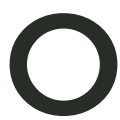
ne day in November 2006, in the meeting room of a human rights NGO in the west of Beijing that was filled with winter sunshine, I had a brief meeting with two AIDS rights advocates and a human rights lawyer to discuss initiating a legal aid and rights advocacy organisation in the field of public health. At that time, I was an active online advocate for the rights of hepatitis B carriers. I was excited about the establishment of such an organisation, but also worried about the future development prospects and potential political risks. Today, when I look back at the fruitful first seven years of the Beijing Yirenping Centre (北京益仁平中心, BYC) and the following seven years in which colleagues were frequently arrested and our offices were raided by 
the police one by one, I cannot help but reflect on the fact that this organisation's history-marked by an uneasy start, subsequent great achievements, and eventual repression-can be seen as the epitome of the times. We started our work in the era of the awakening of civil rights consciousness, and then found ourselves increasingly silenced as the people in power started to turn back the clock to a time in many ways reminiscent of the Cultural Revolution.

\section{Fighting against Discrimination by Legal Means}

After the establishment of the BYC, we quickly decided that our work would focus on the promotion of an anti-discrimination rights movement by legal means. We then gradually expanded our anti-discrimination work from public health fields such as hepatitis B, AIDS, haemophilia, and diabetes to physical appearance, disability, women's rights, LGBT rights, and household registration (户口).

At the end of 2013, the BYC had been in existence for seven years. One morning, I received a web link from a colleague and opened it. It was a list of candidate cases for the '2013 China Top Ten Public Interest Litigation Selection' organised by the media and academic institutions. Among the 28 candidate cases, legal aid cases handled by my colleagues accounted for 13-nearly half! News of these cases, widely spread through mass media and social media, had apparently successfully attracted public attention. At that time, the BYC's tactics, strategies, and principles in policy advocacy seemed to have become a classic model in the Chinese NGO community.

Legal litigation was a strategic choice for us. Under the rule of the Chinese Communist Party (CCP), the police do not allow people to express their demands through assemblies, demonstrations, strikes, and so on, and there is no opposition party or independent parliamentarians to assert these rights in the legislature. NGOs have few ways to have their voices heard by the public and those in power. Fortunately, legal proceedings are allowed. They are conducted in accordance with rules set by the authorities themselves, and they are usually conducted in open procedures. Ordinary people can attend trials and reporters can interview all parties and report the whole process of litigation. Chinese civil society gradually realised that litigation can be used to publicly express their demands, create impact, and promote the rule of law and public policy changes. However, litigation requires specialised legal skills and labour costs. For most individuals, the threshold is high. Professional organisations like the BYC can fully utilise their professional and human resource advantages and make changes through public interest litigation.

In each lawsuit, the BYC always tried its best to create high impact. Specifically, we organised various activities outside the court to attract the attention of people from all walks of life and to get media coverage. For example, we regularly held academic seminars, issued research/survey reports, mobilised the related vulnerable community to send joint letters to the defendant and the court, submitted legislative proposals to the legislature, and conducted performance art (行为艺术) activities outside the court during court sessions. We used to describe this strategy as 'the crucial effort is outside the court' (工夫在庭外) - an expression based on a well-known verse from an ancient Chinese poem: 'the crucial effort is outside the poem' (工夫在诗外).

Our work on hepatitis B discrimination offers many successful examples of this approach. Two cases come to mind. The first case occurred at the end of 2006, when Hewlett-Packard's foundry Calcomp (Suzhou) Co. Ltd, in Jiangsu Province, fired 22 employees because the company's mandatory annual physical examination found them to be hepatitis B positive. Three of these employees filed a lawsuit with the legal assistance of the BYC on 17 May 2007. In August 2007, to support the three victims of employment discrimination, more than 5,000 hepatitis B carriers jointly sent a letter drafted by the BYC to Hewlett-Packard, requesting that the company terminate its cooperation with Calcomp, due to its severe discrimination against hepatitis $\mathrm{B}$ carriers. This joint 
letter-writing action was reported by the Beijing News (新京报), Public Welfare Times (公益时报), Oriental Morning Post (东方早报), Jiangnan Times (江南时报), and other media. This action not only effectively attracted public attention and contributed to policy and legislative changes, but it also successfully protected and won compensation for the victims. In October 2007, Hewlett-Packard issued a written response, in which they stated that on hearing about the situation, they had immediately contacted the supplier and begun to investigate. Shortly after this, the plaintiffs and defendant of the lawsuit reached a settlement following negotiation and the three plaintiffs received satisfactory compensation.

The second case occurred in 2010, when Great Wall Motor Sales Co. Ltd, in Baoding City, Hebei Province, conducted hepatitis B testing during its annual physical examinations of staff. The company then forbade those detected as hepatitis B carriers from eating meals in the company's dining halls and dismissed those who did not conform. A victim of this discrimination filed a lawsuit. On 19 August 2011, two BYC staff travelled to Hong Kong, where they put on a performance art show at the Great Wall Motor Co. Ltd's office. They held a rice bowl in one hand and a pair of chopsticks in the other. Four Chinese characters were written on the bowl, ‘我要吃饭'-a phrase that translates as 'I need to eat', but also means 'I need a job'. This performance attracted a large crowd, including newspaper reporters and TV cameras. Subsequently, Hong Kong's Ming Pao (明報), Sing Tao Daily (星島日報), and other media reported on the protest, and China's Sina.com also reposted the Ming Pao report. As in the first case, this performance art aroused public attention about the issue of hepatitis B discrimination and helped the plaintiffs quickly obtain satisfactory compensation.

According to statistics from the BYC, back in 2003, the Chinese central government had at least 15 laws, regulations, and rules related to hepatitis B discrimination, restricting or even denying rights to employment and education of nearly 120 million hepatitis B carriers in China. However, by no later than 2010, most of these discriminatory laws had been revised. Anti-hepatitis B discrimination lawsuits, most of which involved our organisation, played a primary role in prompting this dramatic change in only seven years.

\section{Performance Art}

Some of the approaches mentioned above in the BYC's advocacy toolkit, such as seminars, research/ survey reports, open letters, legislative proposals, and performance art, are used not only alongside litigation, but also as stand-alone activities for specific cases or issues. Among these tactics, the one that was developed last, but that has consistently had the largest impact, is performance art.

On 19 February 2012, a post about women's rights soared to the top three trending topics on Weibo: young women in Guangzhou had occupied a men's restroom! Some female college students had entered a men's toilet urging other women to leave the long queues for the women's toilets. They also had put up banners with slogans such as 'More convenience for women, better gender equality' and 'If you love her, don't let her wait!'. It was a rare occasion in which Chinese public opinion ended up focusing on issues related to women's rights. The performance was planned during a BYC-sponsored workshop by a small group of female college students with the purpose to call on the government to increase the proportion of public female toilets. Women spend more time in toilets than men; however, for a long time, women's public toilets in China were smaller than men's, causing women to wait longer than men to use the toilet. This performance art action in Guangzhou immediately caused female students to follow suit in Beijing, Chengdu, Wuhan, Nanjing, and other cities. Shortly afterwards, some local governments revised the design standards for urban public toilets and eventually the central government made similar changes.

In China, the earliest NGOs to use 'performance art' to carry out rights protection and legislative advocacy work were environmental NGOs. The BYC's performance art activities began in 2008, after which the centre vigorously promoted and trained organisations and vulnerable/marginalised 


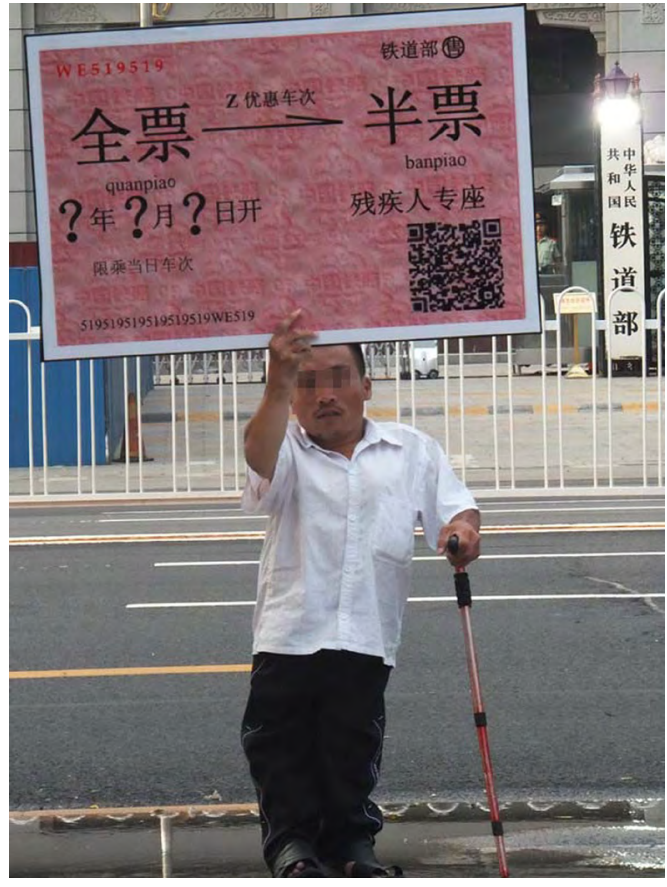

Li Chong (pseudonym), a physically disabled man, holds a self-made, one-metre-square discounted 'train ticket' in Beijing in 2011. PC: Beijing Yirenping Centre.

communities in the use of these techniques. The reason the BYC attached so much importance to performance art was not only because we realised this type of visual art could attract attention and shift public opinion, but also because we believed this small-scale and artistic form of advocacy was a variant of street gatherings, which gave Chinese people the opportunity to exercise a citizen's rights to assembly, demonstration, and protest in a safe manner.

One action that we organised stands out. On the morning of 10 August 2011, Li Chong (pseudonym), a physically disabled man, leaned on crutches and held a self-made, one-metre-square 'train ticket' marked with the word 'discount' at the gate of China's Ministry of Railways. A photo of him holding up the 'ticket' was posted by dozens of media outlets and websites, and Li Chong's story about the difficulties disabled persons faced in riding Chinese trains was heard by people all over the country. Suppose that people with disabilities were to exercise their rights to assemble, demonstrate, and protest at the gate of a heavily guarded national ministry: this action would undoubtedly be stopped by the police even before it could take place. However, when Li Chong stood at the gate of the Ministry of Railways quietly holding his 'ticket', his voice was heard by hundreds of millions of people.

\section{Bottom-Up Approaches}

The BYC was innovative not only externally, but also in its internal organisation. In May 2012, the BYC's board of directors wrote four terms into the organisational charter: equality, rule of law, participation, and inclusion (平等, 法治, 参与, 包容), which accurately summarised the organisational and advocacy principles embodied by the centre over the years. Internally, the BYC stressed diversity by encouraging each project team to form their own unique style, while also supporting employees to run labour unions and anti-sexual harassment committees. Externally, Yirenping supported marginalised groups such as patients, the disabled, sexual minorities, and migrants, aiming to promote a more diverse, more inclusive society.

At the BYC, the mantra was to avoid 'top-level design' (顶层设计) and insist on 'bottom-up' (自下 而上) approaches to make changes. In China, most rights violations can be attributed to the monopoly on power of those in authority and the deprivation of people's freedom. At the BYC, we firmly believed that all the actions of NGOs should serve to promote public participation, while enabling the public to reinforce their ability to defend their rights and seek accountability from the authorities. We did not expect the emergence of a benevolent leader among those in power, nor did we advocate the 'strengthening of government supervision and punishment power' to solve social problems. Rather, we continued to integrate and cooperate with vulnerable and disadvantaged groups. For instance, every year we held the National Conference of Hepatitis B Carriers, helped the disabled to establish working groups, mobilised female college 


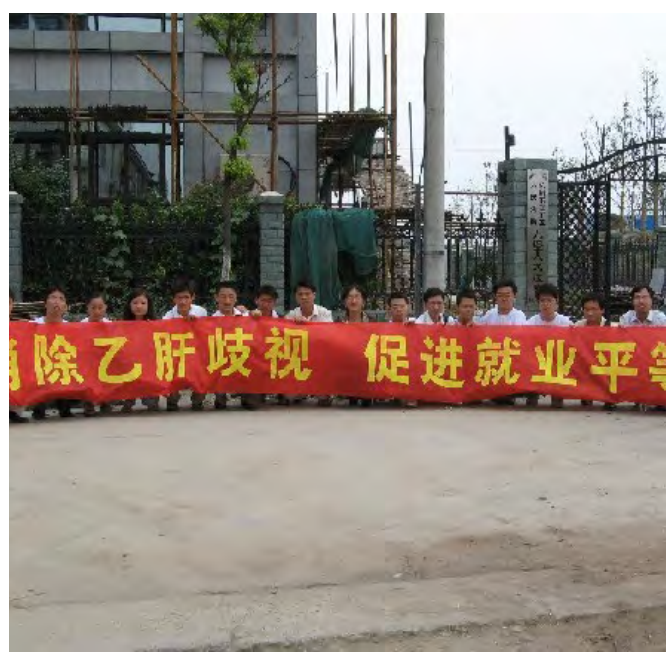

Group photo from an awareness-raising activity on hepatitis B discrimination.

students to conduct feminism training in various cities, and encouraged people from marginalised communities to apply for jobs with us.

At the same time, we prioritised the public sector as the target of our advocacy, rather than individuals or the private sector. The public sector is supported by taxpayers and has an obligation to promote public interests. In addition, the public sector is the initiator of many forms of systematic discrimination. For example, to this day, the Chinese Central Government's Physical Standards for Public Servants' Recruitment (公务员录用体检 通用标准[试行]) classify people living with HIV as 'unqualified', depriving them of the right to be public servants. We found that there is widespread public distaste for misconduct by those in power. If we prioritise those in positions of authority as the targets of criticism when they do something wrong, it can serve to consolidate social consensus. As for human rights violations by individuals and the private sector, we focused on how the violations were responded to by the public authority. For example, we defended the rights of victims of domestic violence, but our goal was to push public authorities to fulfil their anti-domestic violence

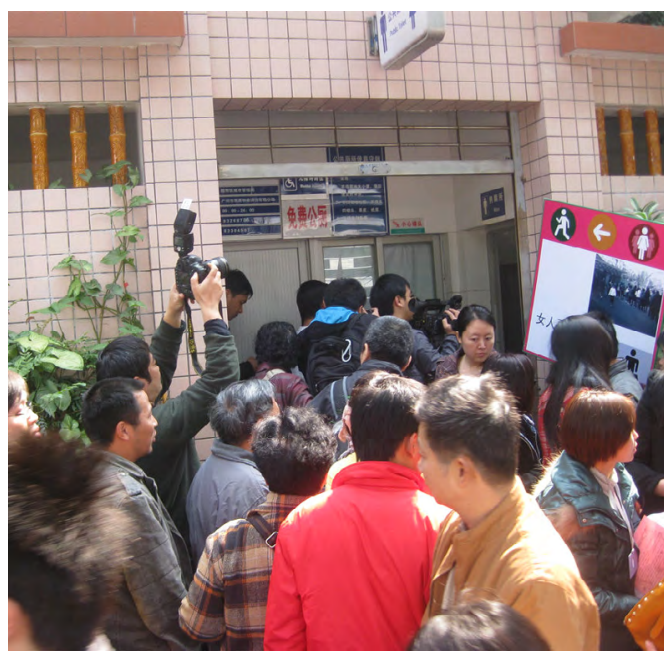

Photo from the 'Occupy Men's Toilet' campaign of 2012. PC: Beijing Yirenping Centre.

duties; we also defended the rights of those with mental disabilities who were sent to mental hospitals by their parents, but our goal was to push the government to stop the systematic abuse of involuntary commitment (精神病人强制收治).

It was our belief that priority should be given to changing the system, not to changing public consciousness. For a Chinese NGO, it is highly inefficient to attempt to eliminate a type of discrimination by changing public perceptions. This would require large-scale and intensive public education/ awareness, but Chinese NGOs do not own the media, or schools, nor do they have the resources to publish books or advertisements. So how can NGOs conduct public awareness programs? Eliminating the public's fear of AIDS and misunderstandings about people living with HIV may take 10 or 20 years through public education. However, removing the government's ban on people living with HIV obtaining a teacher's licence can be achieved within a few years if NGOs can mobilise the community and professionals to work together through legal means and media intervention to create enough pressure on the government. At the same time, this type of action can also promote 
China's rule of law. Shortly after my colleagues provided legal aid for four high-impact lawsuits against HIV employment discrimination in the teaching profession between 2010 and 2012, the Government of Guangdong Province removed the HIV testing requirements in the Physical Standards for the Teacher Licence, in 2013.

Finally, in our work we strove to maintain a balance between a critical stance and constructive expression. When we drafted policy advocacy documents and delivered public speeches, we always reminded ourselves that we were monitors and critics of government behaviour. But to break through news censorship and get media coverage, we needed to present ourselves publicly as a 'suggester' (建言者). For example, in response to unnecessary gynaecological medical examinations during the recruitment process for public servants, we publicly issued an open letter to the central government in March 2012, suggesting they amend or cancel the relevant regulations in the Physical Standards for Public Servants' Recruitment. The essence of this letter was to criticise the government's infringement on the physical privacy and personal dignity of female jobseekers, which was causing employment discrimination, but the format and tone were that of a simple 'suggestion letter'.

\section{Looking Forward}

After 2013, the state's violent suppression of the BYC came without warning. Between 2014 and 2019, in four separate crackdowns, nine of my colleagues were jailed and five of our offices were repeatedly searched until they were shut down. The open and formal operation of anti-discrimination NGOs has now become increasingly impossible. However, what we see today is that a set of rights advocacy methods, strategies, and principles that embodied the wisdom and courage of NGOs of that era, as well as the values pursued by that generation of NGO activists, is still being upheld. At the time of writing in January 2021, it is the coldest season of the year. Compared with the winter 14 years ago, we cannot help but say that although this winter is colder, China's civil society has a more adequate reserve of tools and ideas. We must maintain optimism that one day there will be a more splendid blossoming of a rights movement. 
This text is taken from Made in China Journal: Volume 6, Issue 1, 2021, edited by Ivan Franceschini and Nicholas Loubere, published 2021 by ANU Press, The Australian National University, Canberra, Australia.

doi.org/10.22459/MIC.06.01.2021.12 